\title{
THE FAILURE OF 'NOTICE AND CONSENT' AS EFFECTIVE CONSUMER POLICY
}

\author{
-James P. Nehf
}

\begin{abstract}
One of the central models for consumer protection in most countries emphasizes a notice and consent (or choice) approach--so long as the merchant gives the consumer notice of standard contract terms, and the consumer manifests assent to those terms, the terms are deemed to be binding. In this essay, it is argued that consumer advocates and policy makers should recognize that a notice and consent approach to standard contract terms is not likely to protect consumer interests in modern day contractual settings. Technological advances allow countless standard terms to be imposed on consumers in even the simplest transactions, and manifestations of assent are questionable in many cases. The essay explains why consumers quite rationally may manifest assent to terms and conditions that are not in their interests.
\end{abstract}

\section{INTRODUCTION}

Over the past several decades, the preferred model for consumer protection in most countries has emphasized a notice and consent (or choice) approach with less emphasis on normative laws that prohibit or mandate certain contract terms, acts or practices. In this essay, I argue that it is time for consumer advocates and policy makers to recognize that a notice and

\footnotetext{
James Nehf is a Professor of Law and Cleon H. Foust Fellow at Indiana University McKinney School of Law. Professor Nehf has been teaching contracts, consumer law, and commercial law subjects for thirty years. $\mathrm{He}$ is an internationally recognized expert in consumer privacy and financial services law and serves as a frequent speaker on commercial law subjects at law conferences, CLE seminars, and law-related lecture series worldwide. Professor Nehf's publications include a leading commercial law treatise, Secured Transactions under the Uniform Commercial Code, an updated and revised edition of Corbin on Contracts, and a book on Internet privacy law, Open Book: The Failed Promise of Information Privacy in America. Author can be contacted at jnehf@iupui.edu.
} 
consent approach to standard contract terms and conditions is not likely to protect consumer interests in modern day contractual settings. Indeed, policymakers are doing more harm than good by continuing to focus on notice and consent, thereby giving a misleading impression that consumer interests are being protected when they are not. Moreover, by adhering to a notice and consent regime, they avoid discussing the more difficult yet most fundamental questions about what commercial practices should be permitted and which should be banned.

The European General Data Protection Regulation (GDPR), which is one of the strongest consumer privacy laws in the world, emphasizes notice and consent as one of its central features. ${ }^{1}$ The situation is worse in the United States, as illustrated by the current effort to draft a Restatement of the law of consumer contracts. Recently a team of contract and consumer law experts at the American Law Institute (ALI) released a draft 'Restatement of the Law, Consumer Contracts'. ${ }^{2}$ This new Restatement, focusing solely on consumer contracts, is an attempt to supplement the more general Restatement (Second) of Contract principles, recognizing that consumer contracts present unique challenges and situations that justify special treatment. ${ }^{3}$ The draft recognizes that traditional approaches to contract formation generally favour businesses because they have found little difficulty getting consumers to 'agree' to contract terms without knowing the details or import of what they were agreeing to.

Technological developments online have facilitated this practice, as 'clickwrap' agreements proliferate and consumers find themselves frequently clicking the 'I agree' button realizing that they are agreeing to something but not taking the time (or having the ability) to understand the terms to which they are agreeing. Just using a cell phone app can bind a consumer to countless new terms and conditions. ${ }^{4}$ Thus, the drafters observed that

See Regulation (EU) 2016/679 General Data Protection Regulation, Arts. 6 and 7.

See Restatement of the Law, Consumer Contracts (Tentative Draft, 18 April 2019).

The draft Restatement of consumer contracts has not been approved in its entirety by the ALI yet, a process that can take several years if it happens at all. Even if approved by that body of legal experts, the Restatement has no force of law in the United States until a court or legislature adopts its language. But like the Restatement (Second) of Contracts (and Restatements of the law in numerous other fields), an ALI-approved Restatement addressing consumer contracts could prove influential in the development of consumer contract law across the United States. Courts often use Restatement provisions when deciding cases, and when they do so the Restatement provisions become part of the common law of the United States.

4 The author recently received an e-mail from the Uber ride sharing service stating: "Our updated Terms are effective [on X date] so please make sure to read them fully. If you use 
contract formation process is hardly a process of 'mutual assent'. Despite acknowledging this state of reality, however, the draft Restatement provides that standard contract terms become part of a consumer contract so long as the consumer has been given 'reasonable notice of the standard contract terms' and a 'meaningful opportunity to review them'. ${ }^{5}$ The draft also permits businesses to provide standard contract terms after the consumer has first agreed to the transaction if the consumer has a reasonable opportunity to terminate the contractual relationship after the standard terms are made available for review. Modifications of standard contract terms are covered by these same rules (reasonable opportunity for review and right to terminate).

The draft Restatement as well as the GDPR thus accept the view that, except for the most oppressive contract provisions, ${ }^{6}$ notice and consent should be the governing approach to determining which terms are binding in a consumer-business relationship. The idea is that consumers should be able to make informed and meaningful choices about contract terms and conditions. The accepted norm is that if consumers are presented with contract terms that are comprehensible, and they are given an opportunity to make informed choices, those terms should be binding on them. The guiding principle is that there is an effective market for contract terms-consumers can make informed decisions about the terms that bind them-a market that can be enhanced by effective disclosure and opportunities for people to make decisions.

This ongoing effort to improve the notice and consent model is not surprising. Notice and consent regimes have been recognized as the central part

our app or other services on or after that date, you're confirming you've read and agree to the updated Terms."

5 See Restatement of the Law, Consumer Contracts (Tentative Draft, 18 April 2019), S. 2. The draft does not specify what constitutes "reasonable notice" and "meaningful opportunity to review", although draft Comment 9 states that the standard includes "reasonable indication that they are intended to be part of a legally binding transaction to which the consumer is manifesting assent, and a reasonable opportunity to review the terms. In some contexts, market norms, or course of dealing, may provide sufficient notice to the consumer that additional standard contract terms are intended to apply to the transaction". The draft includes several illustrations of reasonable notice.

- In common law countries, the unconscionability doctrine serves as a check on only the most abusive terms and conditions. See Restatement (Second) Contracts S. 208. See also, Uniform Commercial Code Ss. 2-302 (unconscionability in contracts for sales of goods). The situation is better in Europe, where the Unfair Contract Terms Directive (93/13/EEC) protects consumers against a list of unfair standard contract terms imposed by traders. Similar laws exist in other countries. Limits such as these, however, presume that other terms imposed by the merchant in a consumer contract are enforceable under the mutual assent doctrine until they are declared unlawful by statute or court order. 
of contract formation doctrine for decades. The generally accepted norms girding this regime are openness and transparency, along with faith in the ability of people to act in their best interests. It assumes that consumers can assert their contracting preferences if they are given sufficient information. As the saying goes, failure to read is no excuse. Moreover, it is a lot easier to enact disclosure laws than laws mandating certain terms or prohibiting others. Consumer advocates feel that they have enhanced transparency with the adoption of disclosure laws and business know that disclosures, particularly inconspicuous language, rarely affect consumer behaviour.

While notice and consent may have been an acceptable approach to consumer contract formation many years ago, it is no longer viable following decades of technological advancement that has brought us to the point where, even in the simplest transactions, businesses can get us quickly to 'agree' to dozens of pages of terms and conditions that are designed to insulate the business from liability for just about any type of wrongdoing. In today's digital world notice and consent must be abandoned and supplanted by responsible contracting practices mandated by law (or soft law, e.g., mutual agreement between industry and consumer representatives). The pretense of assent in the modern era must be recognized as a fiction, and rejected. Policy makers or trade associations working with consumer groups must do the hard work and decide what terms and conditions are fair to both parties and insist that they be part of the contract.

In theory, the market-oriented consumer protection model could be made effective by enhanced notice and choice opportunities if individuals were capable of protecting their interests in the modern marketplace. Unfortunately, for many rational reasons, they are neither capable nor interested in doing so and it is time to accept that reality. The remainder of this essay explains some of the reasons why this is so.

\section{LACK OF TRANSPARENCY MAKES DECISION-MAKING PURE GUESSWORK}

Terms and conditions in consumer contracts are becoming more complex and less transparent every day. They are getting longer and less readable because in a digital world because businesses need not present the consumer with a paper document to read prior to entering into a transaction. Imagine a merchant selling someone a $\$ 20$ set of ear phones in a store and giving the customer a 30-page contract to review and sign before the transaction can be completed. Not only would the printing cost to the merchant be 
prohibitive, but the customer would likely be suspicious and wonder why the store needs such a long and detailed contract for such a simple transaction.

Yet today these transactions occur all the time on the Internet, in brickand-mortar stores that require consumers to complete a transaction electronically (e.g., in a cell phone store such as Verizon), and even in homes where contractors (e.g., cable television installers) require customers to click 'I agree' on a tablet before proceeding with the work. Consumers 'agree' to pages of terms and conditions in even the simplest transactions today. No matter how much notice we are given, and even if the terms are written in 'plain' language, we cannot evaluate the risk of potential harms, nor can we make informed decisions, seek redress or stop harms from recurring, because we are not in a position to comprehend the benefits or the risks at the time when a decision has to be made?

\section{VALUING THE INFORMATION IS VIRTUALLY IMPOSSIBLE}

Even with more information and choices available, and even if people actually took the time to read terms and conditions before signalling their agreement, consumers have no idea what to do with all that information. Notice and choice solutions presume that we can value our interests and make decisions in some meaningful way after being presented with the terms. ${ }^{8}$ But with standard terms and conditions there is a high degree of information asymmetry: businesses know how the terms and conditions will protect their interests (they drafted them), but individual consumers do not understand how it may affect them even if they take time to read them all. ${ }^{9}$

Take mandatory binding arbitration provisions, for example. These are prohibited in some parts of the world but increasingly in the United States businesses are including terms in consumer contracts that prohibit class actions, require mandatory binding arbitration of disputes (which can be costly), and require that any challenge to the validity of arbitration provisions be decided by the arbitrator, not a court. Even if a consumer were to read and understand such a provision in the terms and conditions, the provision will not likely have any effect on his or her decision because at the

7 Robert W. Hahn and Anne Layne-Farrar, "The Benefits and Costs of Online Privacy Legislation" (2002) 54(1) Administrative Law Review 85, 103.

8 Curt J. Dommeyer and Barbara L. Gross, "What Consumers Know and What They Do: An Investigation of Consumer Knowledge, Awareness, and Use of Privacy Protection Strategies" (2003) 17(2) Journal of Interactive Marketing 34.

$9 \quad$ See Hal R. Varian, Microeconomic Analysis (3rd edn., 1992) 440. 
time of purchase product failure resulting in damage, and filing a lawsuit (much less a class action) is the farthest thing from the buyer's mind.

\section{ACCURATE CHOICES ARE COMPROMISED BY COMPETING COGNITIVE GOALS}

When making decisions about whether to purchase goods or services, people compromise between their desire for complete accuracy in the decision (balancing all of the costs and benefits of the decision) and their desire to achieve other very rational goals. ${ }^{10}$ Other than maximizing the accuracy of the decision, another important decision making goal is the minimization of cognitive effort. ${ }^{11}$ When making decisions, people tend to expend only as much effort as they need to reach what they perceive is a satisfactory decision, even if it is not optimal in terms of its accuracy. ${ }^{12}$

Unless the decision is of great importance, people tend to make choices that are easier to implement, though less accurate because important factors are left out of the decision making process..$^{13}$ Thus, giving individuals more terms and conditions to read through is not likely to lead to more accurate decisions. Indeed, the longer and more complex the terms and conditions are, the less likely it is that consumers will read any of them. Except for the most obviously sensitive parts of the contract, and perhaps in very large consumer transactions, people are not going to spend the cognitive effort necessary to weigh all of the pros and cons. They will not perceive the stakes being high enough. This behaviour is perfectly rational, and businesses take advantage of it when they draft a long list of terms and conditions highly favourable to their interests.

10 Ellen C. Garbarino and Julie A. Edell, "Cognitive Effort, Affect, and Choice" (1997) 24(2) Journal of Consumer Research 147, 148. See generally, Patricia A. Norberg, Daniel R. Horne, and David A. Horne, "The Privacy Paradox: Personal Information Disclosure Intentions Versus Behaviors" (2007) 4l(1) Journal of Consumer Affairs 100.

11 James R. Bettman, Mary Frances Luce and John W. Payne, "Constructive Consumer Choice Processes" (1998) 25(3) Journal of Consumer Affairs 187, 192.

12 Garbarino and Edell (n 11) 148.

13 Garbarino and Edell (n 11) 149; Eric J. Johnson, John W. Payne, James R. Bettman, "Information Displays and Preference Reversals" (1988) 42(1) Organizational Behavior and Human Decision Processes; Denis A. Lussier and Richard W. Olshavsky, "Task Complexity and Contingent Processing in Brand Choice" (1979) 6(2) Journal of Consumer Research 154. 


\section{PRACTICAL PROBLEMS MAKE STANDARD TERMS AND CONDITIONS LESS SALIENT}

Even if when someone wants to evaluate contract terms and make self-interested decisions based on their content, practical problems create obstacles that impede optimal decision making. Most important are time constraints. When people feel that they should make a decision quickly, people switch from more careful decision-making strategies to simpler ones that result in a quicker decision. ${ }^{14}$ When a tablet is presented to a consumer in a store or at home and she is asked to click 'I agree' before the transaction can continue, there is no time to read terms and conditions. And while there may be plenty of time to read the terms and conditions when a consumer is looking at a website at home, to do so would frustrate one of the principal benefits of going online-a fast and convenient way to learn, communicate, and purchase goods and services. Surfing the Internet would take forever if terms and conditions were evaluated at each site before making a decision of some kind.

\section{BEHAVIOURAL HEURISTICS IMPACT CONSUMER CHOICES}

Several behavioural factors make it unlikely that decisions about contract formation will be made with an accurate balancing of benefits and risks. Inferences play an important role in a person's decision whether to enter into a transaction, yet they often lead to less than optimal choices. If the information necessary to making an informed decision is difficult to obtain, people tend to infer the missing information from other facts that are more readily available. For example, people may assume that a particular attribute of a product or service is similar across brands (e.g., the contract terms and conditions of all banks are probably very similar) or, they may infer a value that corresponds to the values they assign to other attributes of the party with whom they are interacting (e.g., if my personal banker seems trustworthy and caring, the bank's terms and conditions will likely be fair as well). ${ }^{15}$ Some inferences may be justified, but others will be totally inaccurate.

14 John W. Payne and James R. Bettman, "When Time is Money: Decision Behavior under Opportunity-Cost Time Pressure" (1996) 66(2) Organizational Behaviour and Human Decision Processes 131; Peter L. Wright, "The Harassed Decision Maker: Time Pressures, Distractions, and the Use of Evidence" 59 Journal of Applied Psychology (1974) 555.

is Gary T. Ford and Ruth Ann Smith, "Inferential Beliefs in Consumer Evaluations: An Assessment of Alternative Processing Strategies" (1987) 14(3) Journal of Consumer Research 363; Richard D. Johnson and Irwin P. Levin, "More Than Meets the Eye: The Effect of Missing Information on Purchase Evaluations" (1985) 12(2) Journal of Consumer 
Framing effects can also adversely affect the accuracy of decisions. People tend to process information in a way that is consistent with the way it was presented to them, accepting it in its presented form without questioning the details or inquiring further. ${ }^{16}$ These framing effects are wellknown in the marketing industry ${ }^{17}$ and they are most pronounced when the cost of accepting a particular presentation on its face is perceived to be low. ${ }^{18}$ Only if the cost of acceptance is perceived to be high, or if the information is presented in a confusing way, will people discount the form of presentation and seek additional information before making a decision. This is one reason why many links to terms and conditions give little or no information about the content of those terms, nor even hint about their importance. Seldom do you see a warning above the 'I agree' button: 'Beware - by agreeing to our terms and conditions you are giving up your right to sue us if we violate the law and you or your family are injured'. If the presentation form appears safe and unthreatening, individuals are less likely to dig beneath the surface and determine for themselves how the merchant's terms and conditions operate.

Particularly important to contract formation choices, people are not good at making accurate decisions about low-probability risks. People tend either to overestimate the probability and take unnecessary precautions, or they ignore the risk and do nothing. Unless an unlikely occurrence is potentially catastrophic (the slight risk of a home burning causes us to purchase fire insurance), we are not willing to invest much time, money, or effort to reduce or evaluate a risk we think is not likely to occur. ${ }^{19}$

Research 169; B. Wernerfelt, "Umbrella Branding as a Signal of New Product Quality: An Example of Signaling by Posting a Bond" (1988) 19(3) The RAND Journal of Economics 458.

16 W. Kip Viscusi, "Individual Rationality, Hazard Warnings, and the Foundations of Tort Law" (1996) 48 Rutgers Law Review 625, 630-36; W. Kip Viscusi, Wesley A. Magat and Joel Huber, "An Investigation of the Rationality of Consumer Valuations of Multiple Health Risks" (1987) 18(4) The RAND Journal of Economics 465, 477-78.

17 Irwin P. Levin and Gary J. Gaeth, "How Consumers are Affected by the Framing of Attribute Information Before and after Consuming a Product" (1988) 15 Journal of Consumer Research 374.

18 Eloise Coupey, "Restructuring: Constructive Processing of Information Displays in Consumer" (1994) 21(1) Journal of Consumer Research 83.

19 G.H. McClelland, William D. Schulze and Don L. Coursey, "Insurance for Low Probability Hazards: A Bimodal Response to Unlikely Events" (1993) 7(1) Journal of Risk and Uncertainty 95. 


\section{CONCLUSION}

In just the last few years much has changed in the way consumers enter into contracts. Today, we access information and enter into contracts from portable laptops, hand held phones, tablets, e-readers, and other devices at all hours of the day and from land, air, and sea locations throughout the world. Whether it is interaction on social networks or researching the latest news story online, we are constantly entering into contractual relationships on the go. It is not surprising that firms have developed technologies and business plans that create an onslaught of binding terms that were unimaginable a short time ago, and quick ways for consumers to manifest their assent.

Yet despite our recognition of this fictitious form of assent, the draft Restatement of consumer contracts, the GDPR, and many other consumer protection laws today throughout the world, still depend heavily on a notice and consent regime that expects us to police our contracting preferences in situations where we are simply ill-equipped to do so. No matter how clear, conspicuous and timely standard terms and conditions are presented to us; we will seldom make decisions that accurately reflect our preferences. Insurmountable problems regarding the transparency of those terms and conditions, and the practical realities and behavioural tendencies of individuals when they are making decisions about contracting in a digital environment, all render even an enhanced notice and consent approach wholly ineffective. If policy makers are serious about consumer protection, they should move aggressively to ensure that substantive controls and mandatory terms become the norm-terms that are fair to both businesses and consumers-and abandon the outdated notion that consumer interests can be adequately protected by disclosure of contract terms and an individual's manifestation of 'assent' to those terms. 